\title{
Transhumanism, immortality and the question of longevity
}

Transhumanismo: imortalidade e a questão da

longevidade

JoÃO DE FERNANDES TEIXEIRA ${ }^{a}$

\begin{abstract}
The paper focuses on two issues approached by transhumanism: immortality and longevity. The first part presents some contours of the transhumanist program and its motivation. The second discusses the extent to which the promise of immortality cannot be fulfilled by the idea of uploading the brain on the internet. The third part focuses on longevity. It shows why the transhumanist program for the elderly fails.
\end{abstract}

Keywords: Transhumanism. Immortality. Longevity. Upload of the brain on the internet.

Resumo

O artigo enfoca duas questões abordadas pelo transhumanismo: imortalidade e longevidade. A primeira parte apresenta alguns contornos do programa transhumanista e sua motivação. A segunda discute até que ponto a promessa de imortalidade não pode ser cumprida pela ideia de fazer o upload do cérebro na internet. A terceira parte se concentra na longevidade e mostra por que o programa transhumanista para idosos falha.

Palavras-chave: Transumanismo. Imortalidade. Longevidade. Upload do cérebro na internet.

Our bodies are obsolete. Our body has been selected by evolution to be a hunter and a collector, running through the savannah with a spear in hand. Our

\footnotetext{
a Universidade Federal de São Carlos (UFSCAR), São Carlos, SP, Brasil. Doutor em Filosofia, e-
} mail: joaodefernandesteixeira@gmail.com 
anatomy and physiology is the same as 100,000 years ago, but with the advancement of agriculture and tools, it came into conflict with civilization.

We are no longer running through the savannah. We lead a predominantly sedentary life and, as we have been selected to run, we can compensate for this by exercising to prevent muscle loss. We were selected to stock up or get as much glucose as possible so that we could move around the savannah in situations in which food was scarce. Today we have access to food, but our body, still programmed to live in the savannah, continues to accumulate glucose, which causes diabetes damage.

Paradoxically, civilization, created to protect us, is making us the least environmentally friendly animal. Civilization has become an interface between man and his environment, an interface that, to preserve him, also weakens him and makes him sick. In addition, civilization caused our biological evolution to stall. It is increasingly retarded by civilization, which prevents natural selection from occurring. Our engagement with the world has become, increasingly, through the virtual, a medium that offers no physical resistance and only affects our body by weakening it even more by a sedentary lifestyle. Our organism began to live the morbid combination of increased longevity produced by medicine and the involution and weakening of our body.

In a few more decades, the prospect of living 160 years will add to the need to mix more and more with machines to ensure a pumping heart, moving legs, and brain chips for memory conservation. The race for regenerative medicine will have been abandoned as it is realized that it is not enough to keep the body restored, but to extend its physical and mental capacities to ensure survival, a task once performed capriciously and slowly by natural evolution. It will be the age of parabiosis, or our association with dry life forms. This is one of the main flags of transhumanism.

The explicit defense of transhumanist ideals has been circulating in literature and philosophy since the nineteenth century. The English biologist Julian Huxley, a great disseminator of science, already defended the transhumanist ideal that the human being must control and modify the evolution and, with that, perfect its own species. In addition to Huxley, English geneticist John Haldane and, more recently, molecular biology expert John Bernal were also prophets of transhumanism. 
In the 1980s, philosopher Max More formalized a transhumanist doctrine that advocated the improvement of the human species through genetic engineering, robotics, nanotechnology, and techniques for increasing longevity. In 1998, philosophers Nick Bostrom and David Pearce founded the World Transhumanist Association and wrote the Transhumanist Declaration in which they are committed to the reform of human nature through science. One of the great bets of contemporary transhumanists for the betterment of future human generations is the manipulation of the genetic code and, with it, an interference in the course of evolution. According to them, so far, evolution has been just a large set of trial and error, of improvisations that have taken place over thousands of years. The project of transhumanists is to direct it more efficiently by controlling unnecessary mutations.

The manipulation of the genetic code will also allow an expansion of human cognition. That is, our symbiosis with machines will also lead to the expansion of intelligence. The promise of transhumanists is that of a new generation that will emerge from our symbiosis with machines. We will have chips implanted in the brain that will allow us to speak and write in English, French or German effortlessly, and reason and manipulate data with the speed of a supercomputer. Our memory can be greatly expanded through a brain chip that connects directly to Google. There will also be a new generation of genetically modified athletes more resilient and competitive by the use of prosthetics.

The genes responsible for intelligence are many and their interactions are multiple, which makes the study of their operation extremely difficult. The study of the functioning of these genes could be done in the near future by nanotechnology. It will allow nanorobots to be sent to the brain that will scan the neurons and their genetic code with immense precision. We will know exactly which genes produce intelligence and which inhibit it.

The sheer amount of data generated by these nanorobots will require greater intelligence than human to compute them, but we can count on the help of superintelligences. Artificial intelligence will help rewrite the human genetic code, making us more intelligent and capable. Supercomputers can recalculate and hasten the course of mutations that are beneficial to the human brain. This is the expected big leap in the combination of genetic engineering, nanotechnology and artificial intelligence. 
This biotechnological reform is part of the theoretical program of the transhumanists, who have now grown into the ranks of technoutopia. They predict a longer and better life for humans, free from chronic and degenerative diseases. Nick Bostrom and Jean Savulescu, who are among the best known transhumanists, clearly propose human genetic reprogramming, and without fear of being accused of eugenics. Several transhumanists outright attack the possibility of parents refusing in future to manipulate their children's DNA. They claim that taking refuge under nature's genetic lottery would be nothing but a way of evading the new moral responsibilities that will be imposed in the coming decades.

Already in the 1970s, the American philosopher Robert Nozick (1973) stated that we would soon have a genetic supermarket in which parents could choose the characteristics they wanted for their children. This prediction is coming true, especially with the development of genome editing through CRISP-R techniques developed by biologist Jennifer Doudna.

According to some transhumanists, such as physicist Michio Kaku, the only way to preserve the human species is to perfect it through genetic manipulation or progressive association with machines. They have become imperative for the survival of our species. From the point of view of the ability to process information from the environment, our brain is already obsolete and therefore genetic or neuroprosthesis improvement is an inevitable and urgent task. We need to live up to the technology we produce so that we do not become obsolete or dominated by it.

\section{Digital immortality}

Teen Bethany, character from the HBO streaming series Years and Years dreams of becoming transhuman, which means for her to implant various technologies into her body and finally upload her brain to the internet completely. To live forever. Some radical transhumanists, such as Ray Kurzweil, claim that around year 2100 we can become immortal by completely uploading our brains to the internet. Internet upload is not a philosophical issue for transhumanists, as, just as our bodies renews every seven years, by completely replacing cells without losing 
personal identity in time, we can also imagine the existence of various versions of ourselves in space without conflicting with each other. If we become holographs, we can be projected simultaneously to various places in space, not only on the internet, but also in other universes of the multiverse.

However, there is no consensus among the philosophers of the mind about the possibility of this upload. The simulation of the human brain is not its replication, so its uploading to the internet from a digital description could generate only a huge virtual graveyard populated with holographs of humans. Images have no life. The basis for intentionality and consciousness is life.

It would be interesting to ask why this kind of fantasy with immortality arises in the imagination of a teenager like Bethany. We always want to live longer and the idea of eternal life is a kind of contradictory desire that haunts us. The paradox of immortality is that without finitude life loses its meaning. Achieving immortality could never be a fact, but only a wish. Although death is not part of life because it is beyond conscious experience, finitude is one of the essential components of life. More than dying, the important thing is to know that we will die. The brevity of life and the uncertainty about when it will end is what makes us struggle to make it as dignified as possible. An infinite or extremely long life is incompatible with the idea of establishing values, priorities, and the desire to make the best of it.

It is this paradox that seems to define us as human, because the desire to prolong life is always accompanied by another, that of entering some Nirvana that will follow the end of existence. The desire for a Nirvana is commensurate with the difficulty of living that we encounter on a daily basis. This is Bethany's escapism. It is the realization that life is becoming unbearable. That we will not resist climate change, the radical devaluation of human labor by algorithms or the epidemics caused by overpopulation. Bethany wants to escape this world in a radical way: by uploading her brain to the cloud and thereby gaining eternal life as well. The question from a philosophical point of view is whether this is conceptually possible. I think not.

Imagine, as in the famous mental experiment invented by seventeenthcentury philosopher John Locke, that someone, while you sleep, exchanges all the memories in your brain with someone else's. Locke states that in this case you would lose your personal identity, which would be replaced by someone else's. 
However, would you acquire someone else's identity if you were not able to recognize these new memories as your own?

Perhaps this explains why a robot that stores large amounts of information would not be able to generate a self. How could this machine give your information the characteristic of "being hers"? Wittgenstein emphasized the great difficulty involved in defining what my representations mean. This is the crux of the subjectivity, an issue that occupied philosophers in recent centuries. Much of the difficulty seems to derive from the fact that "being mine" does not appear to be a trait that can be identified in a given set of representations. A house or the representation of a house changes nothing because it is mine or not. If "being my representations" were a representation, it would take another representation to make it mine. It would be a return to infinity. Therefore, "being my representations" has to be something non-conceptual, that is, it cannot take the form of a mental state or a proposition. This is why it is not possible to represent “being my representation”.

Then we return to the situation of our friend Bethany. If these conjectures are correct, she cannot be transformed into a file that could be sent to the cloud without losing her self, while being subjectivity. Bethany would no longer be Bethany.

It is a pity. It seems that we cannot use an upload of our brains on the internet to escape a hostile world or to reach eternal life. The transhumanists must forgive me. Life will continue to be an addiction that we cannot get rid of. The alcoholic gets drunk and feels pleasure. Nevertheless, it is always punished and despised by family and society. Paradoxically, he drinks again, though his punishment is greater than his reward. This seems to be the cycle that binds us to life. That we want it to be eternal yet unbearable.

\section{Longevity}

Sometimes the transhumanist discourse adopts a hyperbolic tone, such as the idea that we will be able to become immortal. However, there is an important warning that serves as the backdrop to these speculations: aging. In the last decades, the expectation of living more expanded dramatically, which, however, was not 
accompanied by the quality of life. This fact did not go unnoticed by the transhumanists.

The world population is becoming increasingly long-lived. The average global life expectancy has risen from 65 to 72 years in the last two decades. Europe is a vast continent of old people. In the United States, many people already live more than 100 years. Soon, China will have over 100 million seniors. Old age will also be epidemic in developing countries.

Globalized old age is a huge social problem, especially when many older people, from 80 or 90 years old, lose their autonomy. Many have suffered falls and lost mobility, others face Alzheimer's. When old age enters this stage, the elderly depend on geriatric nurses and other types of caregivers. Therefore, most of the time, they are taken to specialized institutions.

The consequences are devastating. These elderly people lose their homes and live in restricted spaces, in a long waiting line for death in which care is confused with segregation. Millions of seniors spend their last years staring at nothing, pacified by soap operas and tranquilizers.

Medicine has provided us with a quantitative gain in longevity, but not a qualitative one. People are born at one time and die at another. They die in a different world that they cannot understand. Never have so many generations come to live and share such a different worldview. Older people are becoming increasingly caricatured people with old-fashioned ideas and attitudes. What good is living 160 years if we cannot get out of bed in the last 20 years? Perhaps a long life is not a blessing, and many philosophers have warned of it. In the seventeenth century, the Englishman Thomas Hobbes (1588-1679) stated that human life at its beginning was "lonely, poor, dirty, brutal and short." Centuries later, Freud, resenting the weight of age, stated, "What good is a long life if one is so miserable, so poor in joy and rich in suffering that death can only be hailed as a liberation?"

In 2007, transhumanist Aubrey De Gray published the book Ending Aging: The Rejuvenation Breakthroughs that Could Reverse Human Aging in which he predicts that we can live for a thousand years. He believes that in the coming decades we will discover a cure for diseases that occur in old age and lead to premature death, such as Alzheimer's, heart problems and diabetes. But not only that. Overcoming these 
obstacles, we will begin to treat aging itself as a disease that we need to cure. De Gray proposes a package of various types of treatments, the longevity escape velocity (LEV), designed to restore the wear and tear that organisms suffer over time.

Some mouse experiments point out that De Gray may be on the right track. Undergoing new treatments, they now live 1,500 days when their average life is about 360. However, we know that animal testing, besides being ethically controversial, is insufficient. To take a final step, we need to test new drugs and treatments in humans.

Nevertheless, it is precisely this final step that leads to an ethical dilemma. Normally, human volunteers to test new drugs are people with incurable diseases, with no expectation to survive much longer. This is not the profile of volunteers De Gray needs in order to test his treatments. It would be useless to test them on elderly patients, with health compromised by old age diseases, as this would interfere with the results. Tests are needed on healthy elderly, still rare today, but which, according to De Gray, will be a majority in the coming decades, when we have the cure for diseases that lead to premature death. How to convince a healthy person to risk their life?

Imagine a person over 80, physically and mentally active, without heart problems, diabetes, or Alzheimer's symptoms. This person may only suffer from some minor health disorder, such as mild high blood pressure, controlled by continuous-use medications. Would this person accept risking the remaining years of life in exchange for the possibility of living another 3 or 4 decades? Undergoing treatment that has never been tested before? It is a very difficult choice.

Many elderly millionaires are willing to pay fortunes to extend their life. They could convince some very poor person to risk testing the treatment in exchange for leaving too much money for their family should he fail. In addition to being ethically inadmissible, this could become a scandal in the international media. Perhaps we can only wait for the gradual advances in medicine. 


\section{Conclusion}

Transhumanism is still visionary. However, futuristic scenarios can serve to mount mental experiments that allow discussing philosophical, social and ethical implications of technology. These scenarios also serve as a warning for what may happen in the not too distant future and how we might respond to increasingly threatening living conditions.

\section{References}

De GRAY, A. Ending Aging: The Rejuvenation Breakthroughs that Could Reverse Human. Cambridge: Fringe FM, 2007/2018.

BOSTROM, N. Superintelligence: Paths, Dangers, Strategies. Oxford: Oxford University Press, 2016.

FREUD, S. Edição Standard brasileira das obras psicológicas completas de Sigmund Freud. Rio de Janeiro: Imago, 1969.

HOBBES, T. Leviatã ou a matéria, forma e poder de um estado eclesiástico e civil. São Paulo: Martins Fontes, 1651/2014.

KURZWEIL, R. A Era das Máquinas Espirituais. São Paulo: Aleph, 1999/2007.

MEHLMAN, M. Transhumanist Dreams. Baltimore: John Hopkins University Press, 2012.

MORE, M.; VITA-MORE, N. The Transhumanist Reader. Oxford: Wiley-Blackwell, 2013.

NOZICK, R. Anarchy, State and Utopia. New York: Basic Books, 1973.

SAVULESCU, J.; BOSTROM, N. Human Enhancement. Oxford: Oxford University Press, 2009.

RECEIVED: $11 / 02 / 2019$

APPROVED: $12 / 02 / 2019$

RECEBIDO: 02/11/2019

APROVADO: 02/12/2019 